\title{
FOUR NEW RECORDS OF DAMSELFISH (POMACENTRIDAE) FROM SAINT MARTIN'S ISLAND, BANGLADESH
}

\author{
Md. Jayedul Islam ${ }^{1}$ and Kazi Ahsan Habib²* \\ ${ }^{1}$ Aquatic Bioresource Research Lab, Department of Fisheries Biology and Genetics, \\ Sher-e-Bangla Agricultural University, Dhaka 1207, Bangladesh \\ ${ }^{2}$ Department of Fisheries Biology and Genetics, Faculty of Fisheries, Aquaculture \\ and Marine Science, Sher-e-Bangla Agricultural University, Dhaka 1207, \\ Bangladesh
}

\begin{abstract}
Four species of damselfish viz., Pomacentrus proteus Allen, 1991; Pomacentrus similis Allen, 1991; Stegastes obreptus (Whitley, 1948) and Pomacentrus adelus Allen, 1991 have been recorded for the first time from the marine water of Bangladesh in the Saint Martin's Island. The species were observed and captured photographs during monthly underwater survey from January to March 2018 on coral associated fishes in the Saint Martin's Island located at the northern Bay of Bengal, Bangladesh.
\end{abstract}

Key words: The Bay of Bengal, Saint Martin's Island, Damselfish.

\section{INTRODUCTION}

The fishes of the family Pomacentridae generally known as damselfish. Pomacentridae is a highly diverse family of reef fishes comprising approximately 416 species of 29 genera and four subfamilies that primarily inhabit tropical and temperate shallow waters around the world, with the majority of species occurring in the Indo-west and central Pacific region (Allen 1991, Helfman et al. 1997, Allen 1998,Thresher 1984, Litsios et al. 2012, Nelson et al. 2016, Froese and Pauly 2019, Fricke et al. 2020). Damselfishes generally occurs in tropical reef habitats but very few species are found in fresh and brackish water such as Neopomacentrus aquadulcis, N. taeniurus, Pomacentrus taeniometopon, Stegastes otophorus etc. (Kohda 1984, Jones \& Andrew 1990, Jones 1992, Jenkins and Allen 2002). Some damselfish lives on rocky areas or sea grass beds but most of the damselfishes occurs into the shallow water between the depth of 2 and 15 meter (Thresher 1984, Bohlke and Chaplin 1994, Helfman et al. 1997, Hoese and Moore 1998, Allen 1998). These fishes usually are less than 15 centimeters whereas some of the species reach the maximum length of $35 \mathrm{~cm}$ (Allen 2001, Froese and Pauly 2019). Damselfish plays a role to modify and influence algae, mesoin vertebrates and benthic communities, and make social structure of other herbivores fishes (Lobel 1980, Montgomery 1980a, Sammarco1983, Hixon and Brostoff 1983, Klumpp et al. 1987). There are only 22 species of damselfish have been recorded in Bangladesh (Hussain 1970, Tomascik 1997, Rahman et al. 2009 and Thompson et al. 2010) whereas 52 species were recorded from India, and a total of 138 species of damselfish were reported from Indian Ocean

*Author for correspondence:<ahsan.sau@gmail.com>

(C2020 Zoological Society of Bangladesh DOI: https://doi.org/10.3329/bjz.v48i1.47876 
(Venkataraman and Raghunathan 2015, Nair and Dinesh Kumar 2018, Froese and Pauly 2019). This paper describes the new record of four damselfish species with their inventory in Bangladesh.

\section{MATERIAL AND METHODS}

Underwater observation: The fishes were observed and captured photographs during monthly underwater survey by scuba diving in water depth of about 3$5 \mathrm{~m}$ from January to March 2018 in the southernmost part (locally called "Chera Dwip") of the Saint Martin's Island. The Saint Martin's Island is located at the southernmost tip of Bangladesh in the northern Bay of Bengal (Coordinates: $20^{\circ} 34^{\prime}-20^{\circ} 39^{\prime} \mathrm{N}$ and $92^{\circ} 18^{\prime}-92^{\circ} 21^{\prime} \mathrm{E}$ ) separated from the mainland by a channel that is about $9 \mathrm{~km}$ wide (Figure 1). Species were identified based on the morphological features of the photographs of fishes (Figure 2 to 5) followed by the description of Allen et al. (2003), Allen (2001), Allen (1991) and Rahman et al. (2009).

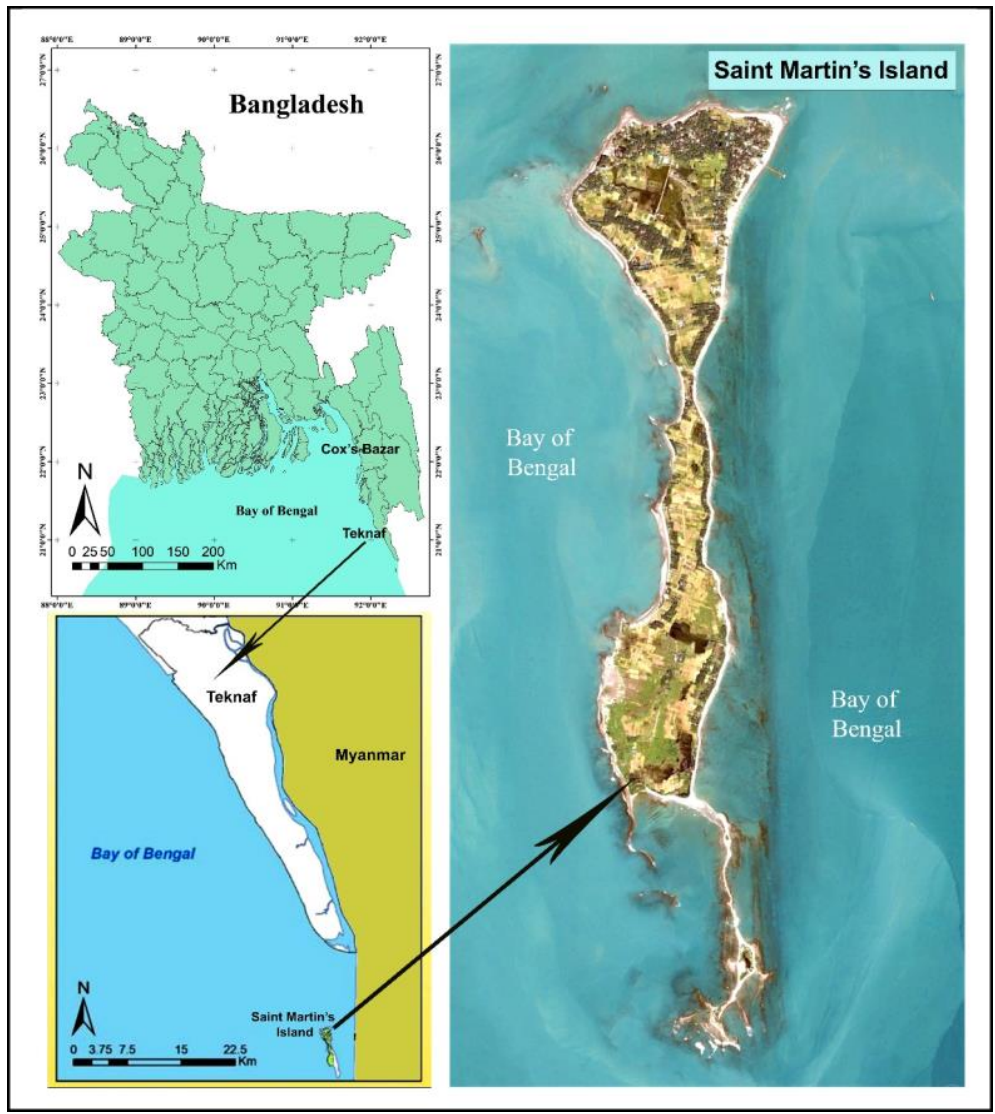

Fig. 1. Map of the Saint Martin's Island and its location in Bangladesh. 


\section{RESULTS AND DISCUSSION}

We identified 7 damselfish during our survey from which 4 species viz., Pomacentrus proteus Allen, 1991; Pomacentrus similis Allen, 1991; Stegastes obreptus (Whitley, 1948) and Pomacentrus adelus Allen, 1991 are the first distributional records for Bangladesh. Taxonomic account of these 4 new records describe hereunder:

\section{Pomacentrus proteus Allen, 1991}

(Colombo damsel)

Material examined: Photographs of the species were taken from Bangladesh:

Cox's Bazar, Teknaf, St. Martins Island, Bay of Bengal (Figure 1). An underwater photograph was captured of $P$. proteus around 3 meter of depth in the southernmost of the St. Martin's Island (Fig. 2).

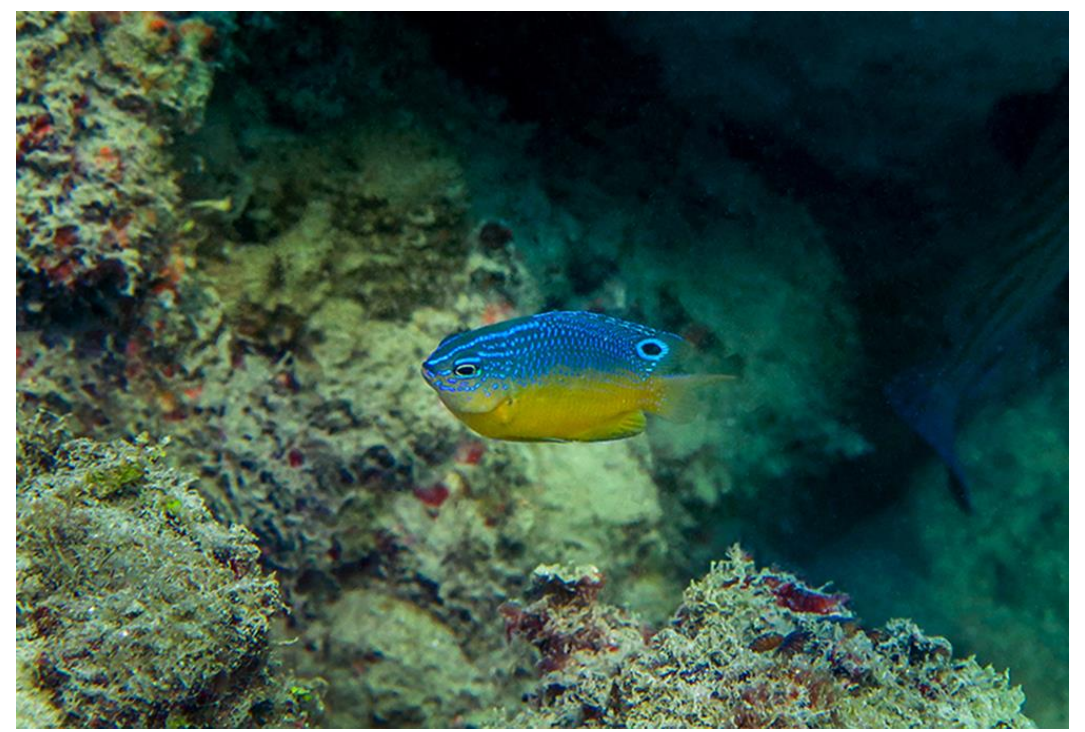

Fig. 2. Pomacentrus proteus. Photo captured from Chera Dwip of Saint Martin's Island.

Diagnosis: Color of head blue and back gradating in yellow below, neon blue line markings presents on upper head and blue spotting below. A large neon blue edge black spot present on the middle of the soft dorsal fin

Remarks and Distribution: Pomacentrus proteus was identified by its special body coloration. It is distinguished from its closely related species $P$. milleri Taylor, 1964 by its local distribution. Pomacentrus milleri is restricted to Eastern Indian Ocean: northern Australia, from Rottnest Island (off Perth) to Arnhem Land, Northern Territory (Allen et al., 2003 and Froese and Pauly 2019). Pomacentrus 
proteus known to occurs from Srilanka, Myeik Archipelago (questionable), Andaman sea and Thailand (Allen et al. 2003, Russel 2016, Howard 2018, GBIF 2019a, Froese and Pauly 2019). However, no valid record found in the Northern Bay of Bengal (Hussain 1970, Tomascik 1997, Allen 2001, Rahman et al. 2009, Thompson 2010, Venkataraman and Raghunathan 2015, Russel 2016, Nair and Dinesh Kumar 2018, Howard 2018, GBIF 2019a, Psomadakis et al. 2019, Froese and Pauly 2019). Therefore, this report confirm the first distributional record of Pomacentrus proteus in the Northern Bay of Bengal.

\section{Pomacentrus similis Allen, 1991}

(Similar damsel)

Material examined: Photograph of fish collected from Bangladesh: Cox's Bazar, Teknaf, St. Martins Island, Bay of Bengal (Figure 1). An underwater photograph of $P$. similis was captured around $3 \mathrm{~m}$ of depth in the southernmost side of the St. Martin's Island (Figure 3).

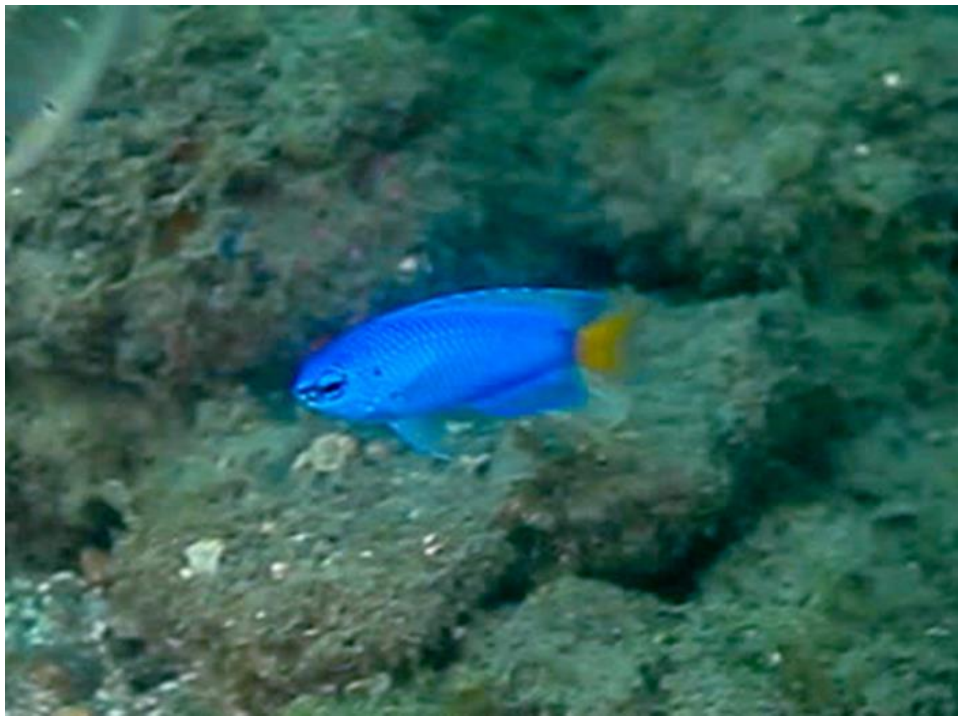

Fig. 3. Pomacentrus similis. Photo taken from Chera Dwip of Saint Martin's Island.

Diagnosis: Body relatively elongate and compressed. Body color deep blue, tail pale yellowish in color, and ventral fins blackish in color. Caudal fin yellowish with dusky posterior margin.

Remarks and Distribution: Pomacentrus similis was identified by its coloration. Pomacentrus similis known to occurs from the Indian Ocean: Sri Lanka, Andaman Sea, Myeik Archipelago, Thailand and Philippines (Allen et al. 2003, 
Russel 2016, Howard 2018, GBIF 2019b, Froese and Pauly 2019). However, there is no valid record of this species from the Northern Bay of Bengal, Bangladesh (Hussain 1970, Tomascik 1997, Allen 2001, Rahman et al. 2009, Thompson 2010, Venkataraman and Raghunathan 2015, Russel 2016, Nair and Dinesh Kumar 2018, Howard 2018, Psomadakis et al. 2019, Froese and Pauly 2019). Therefore, this report confirms the first distributional record of Pomacentrus similis species in the Nothern Bay of Bengal, Bangladesh.

\section{Pomacentrus adelus Allen, 1991}

(Obscure Damsel)

Material examined: Photographs captured from Bangladesh: Cox's Bazar, Teknaf, St. Martins Island, and Bay of Bengal (Figure 1). An underwater photograph was captured during the foraging of Pomacentrus adelus around $4 \mathrm{~m}$ of depth in the southernmost side of the St. Martin's Island (Fig. 4).

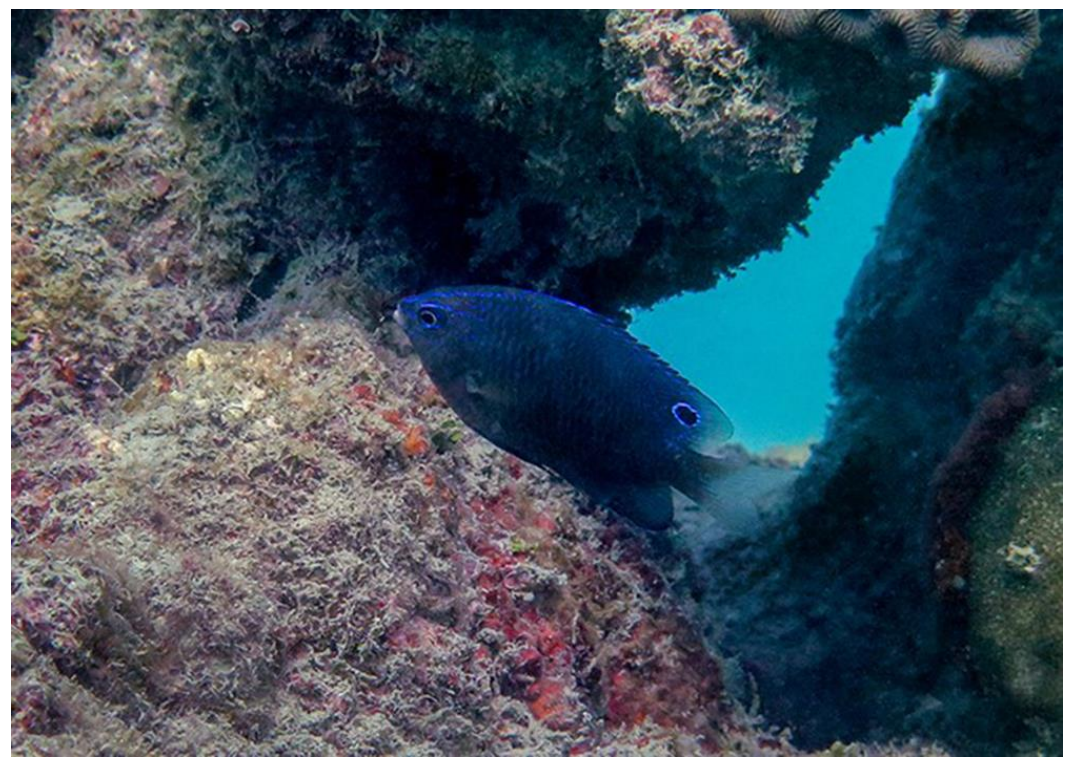

Fig. 4: Pomacentrus adelus. Photo captured from Chera Dwip of Saint Martin's Island.

Diagnosis: Body ovate; color of head, body and fins blackish brown; ocellated spot with neon blue edge present on posterior part of dorsal fin; some blue lines on head, numerous blue dots on head and body; sky-edged black ocellus on posterior part of dorsal fin (Fig. 4).

Remarks and Distribution: Pomacentrus adelus known to occurs from Western Pacific: Myeik Archipelago, Andaman Sea to Vanuatu, Tonga north to the Philippines, south to northern Australia and New Caledonia (Myers 1999, 
Randall et al. 2003, Russel 2016, Howard 2018, GBIF 2019c, Froese and Pauly 2019). However, there is no valid record of this species from Bangladesh (Hussain 1970, Tomascik 1997, Allen 2001, Rahman et al. 2009, Thompson 2010). Therefore, this report confirms the first distributional record of Pomacentrus adelus in Bangladesh waters.

\section{Stegastes obreptus (Whitley, 1948)}

(Western Gregory)

Material examined: Photographs of the species collected from Bangladesh: Cox's Bazar, Teknaf, St. Martins Island, Bay of Bengal (Figure 1). An underwater photograph was captured during the foraging of Stegastes obreptus around $4 \mathrm{~m}$ of depth in the southernmost side of the St. Martin's island (Figure 5).

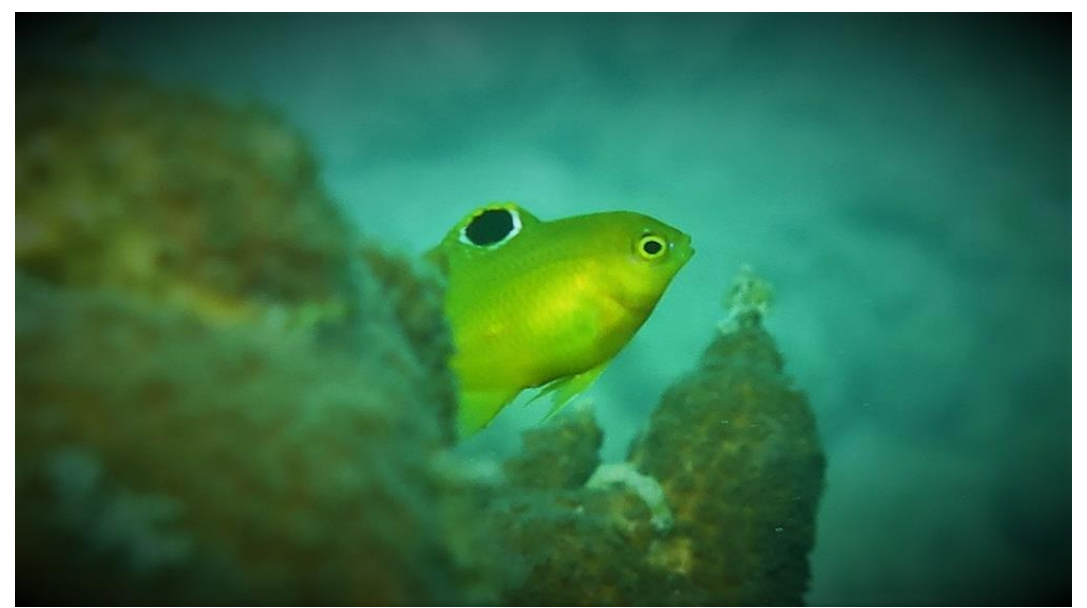

Fig. 4: Stegastes obreptus. Photo taken from Chera Dwip of Saint Martin's Island.

Diagnosis: Body moderately deep; mouth terminal and slightly oblique. Juvenile body color yellow with narrow dark scale margins; blue spot on head. Large black spot with yellow blue edging on front of dorsal fin.

Remarks and distribution: Western Gregory was distributed in Indo-Pacific: Ryukyu Islands, Indo-Malayan Archipelago, North to south Japan, Western Australia north of Abrolhos Islands; Tropical Indian Ocean to Sri Lanka, Myeik Archipelago and India (Venkataraman and Raghunathan 2015, Russel 2016, Howard 2018, Nair and Dinesh Kumar 2018, GBIF 2019d, Froese and Pauly 2019). However, there is no valid record of this species from Bangladesh (Hussain 1970, Tomascik 1997, Allen 2001, Rahman et al. 2009, Thompson 2010). Therefore, this is the first report of Stegastes obreptus from Bangladesh waters. 
Table 1: An updated checklist of Damselfish of Bangladesh

\begin{tabular}{|c|c|}
\hline Species name & References \\
\hline Abudefduf bengalensis & Rahman et al. 2009 \\
\hline Abudefduf septemfasciatus & Rahman et al. 2009 and Present Study \\
\hline Abudefduf sexfasciatus & Rahman et al. 2009 \\
\hline Abudefduf sordidus & Tomascik 1997 and Present study \\
\hline \multicolumn{2}{|l|}{ Amphiprion ephippium } \\
\hline Amphiprion percula & Rahman et al. 2009 \\
\hline \multicolumn{2}{|l|}{ Chromis caerulea } \\
\hline $\begin{array}{l}\text { Chrysiptera brownriggii } \\
\text { Coris gaimard }\end{array}$ & Tomascik 1997 \\
\hline \multicolumn{2}{|l|}{ Cheiloprion labiatus } \\
\hline Dascyllus marginatus & Rahman et al. 2009 \\
\hline \multicolumn{2}{|l|}{ Dischistodus perspicillatus } \\
\hline Neopomacentrus zysron & Tomascik 1997 \\
\hline Neopomacentrus cyanomos & Tomascik 1997 and Present study \\
\hline Pomacentrus adelus & Present study \\
\hline $\begin{array}{l}\text { Pomacentrus caeruleus } \\
\text { Pomacentrus coelestis }\end{array}$ & Tomascik 1997 \\
\hline Pomacentrus tripunctatus & Rahman et al. 2009 and present study \\
\hline Pomacentrus similis & Present study \\
\hline Pomacentrus proteus & Present study \\
\hline Pomacentrus vaiuli & Tomascik 1997 \\
\hline Premnas biaculeatus & Rahman et al. 2009 \\
\hline \multicolumn{2}{|l|}{ Pristotis obtusirostris } \\
\hline Stegastes fasciolatus & Tomascik 1997 \\
\hline Stegastes lividus & Rahman et al. 2009 \\
\hline Stegastes obreptus & Present study \\
\hline
\end{tabular}

Damselfish is the most diverse group of reef fishes of Bangladesh. During our entire survey period, we identified seven species of damselfish from Saint Martin's Island, Bangladesh. The Saint Martin's Island is the only Island in Bangladesh that supports coral ecosystem. The unique coral habitat of this island supports a great diversity of marine animals. Among seven identified species, 4 damselfish e.g. Pomacentrus proteus Allen, 1991; Pomacentrus similis Allen, 1991; Stegastes obreptus (Whitley, 1948) and Pomacentrus adelus Allen, 1991 have been recorded for the first time from the marine water of Bangladesh in the Saint Martin's Island.

Therefore, previously 22 damselfish were recorded from Bangladeshi water (Hussain 1970, Tomascik 1997, Rahman et al. 2009, Thompson 2010, Froese 
and Pauly 2019). Sourcing from different valid reports including present study, we have updated the checklist of damselfish of Bangladesh (Table 1) which indicates that 26 species of damselfish have been reported in the country until now. This study indicates the possibility of existence of more species of damselfish in Bangladesh that have been overlooked in past surveys.

Acknowledgements: This research has been carried out by a competitive research grant (CRG) of NATP-2 project of the Bangladesh Agricultural Research Council (BARC), and UNESCO/Korean Funds-in-Trust funded DMREEF project of IOC/WESTPAC. We are thankful to S. M. Atiqur Rahman and Sharif Sarwar for working with us in underwater exploration and capturing photographs. We also acknowledge Gerald R. Allen for his valuable comments.

\section{LITERATURE CITED}

ALLEN G. R. 2001. Pomacentridae. In: Carpenter, K.E. and Niem, V.H. (eds) FAO species identification guide for fishery purposes. The living marine resources of the Western Central Pacific. Bony fishes part 3 (Menidae to Pomacentridae). Rome, FAO. Volume 5,2791-3380.

ALLEN, G. 1998. Damselfishes. In: ESCHMEYER, W., PAXTON, J eds. The World Encyclopaedia of Fishes - second edition. San Diego, CA: Academic Press, 205-208.

ALlEN, G.R., STEENE, R., HUMANN, P. and DELOACH, N., 2003. Reef fish identification: tropical Pacific. New World Publications Incorporated 457 pp.

BOHLKE, J., CHAPLIN, C., 1994. Fishes of the Bahamas and Adjacent Tropical Waters. Wynnewood, Pa: Published for the Academy of Natural Sciences of Philadelphia by Livingston, $771 \mathrm{pp}$.

FRICKE, R., ESCHMEYER, W. N. \& FONG, J. D. 2020. Eschmeyer's Catalog of Fishes: Species by Family/subfamily.(http://researcharchive.calacademy.org/research/ichthyology/catalog/Spe ciesByFamily.asp).Electronic version accessed 10/03/ 2020.

FROESE, R. and Pauly, D., (Ed.). 2019. FishBase. World Wide Web electronic publication. www.fishbase.org, version (12/2019). Electronic version accessed 10/03/ 2020.

GBIF, 2019a. Pomacentrus proteus Allen, 1991 in GBIF Backbone Taxonomy. Checklist dataset https://doi.org/10.15468/39omei accessed via GBIF.org on 2020-03-27.

GBIF, 2019b. Stegastes obreptus (Whitley, 1948) in GBIF Backbone Taxonomy. Checklist dataset https://doi.org/10.15468/39omei accessed via GBIF.org on 2020-03-27.

GBIF, 2019c. Pomacentrus similis Allen, 1991 in GBIF Backbone Taxonomy. Checklist dataset https://doi.org/10.15468/39omei accessed via GBIF.org on 2020-03-27.

GBIF, 2019d. Pomacentrus adelus Allen, 1991 in GBIF Backbone Taxonomy. Checklist dataset https://doi.org/10.15468/39omei accessed via GBIF.org on 2020-03-27.

Helfman, G., COllete, B., and FACEY, D., 1997. The Diversity of Fishes. Second edition. Malden, MA: Blackwell, 736 pp. 
HIXON, M.A. and BROSTOFF, W.N. 1983. Damselfish as keystone species in reverse: intermediate disturbance and diversity of reef algae. Science, 220(4596): 511-513.

HOESE, D., MOORE, R., 1998. Fishes of the Gulf of Mexico: Texas, Louisiana, and adjacent waters second edition. College Station, TX: Texas A\&M University Press, 416 pp.

HOWARD, R. (Ed.). 2018. Marine Biodiversity of Myeik Archipelago: Survey Results 2013-2017 and Conservation Recommendations. Tanintharyi Conservation Programme, a joint initiative of Fauna \& Flora International, the Myanmar Forest Department and Department of Fisheries, $138 \mathrm{pp}$.

HUSSAIN, M.M. 1970. Marine and Estuarine Fishes of the North-East Part of Bay of Bengal. Scientific Researches. East Regional Laboratories, Pakistan. 7(1): 26-55.

JENKINS, A.P. and ALLEN, G.R. 2002. Neopomacentrus aquadulcis, a new species of damselfish (Pomacentridae) from eastern Papua New Guinea. RECORDS-WESTERN AUSTRALIAN MUSEUM, 20(4): 379-382.

JONES, G.P. 1992. Interactions between herbivorous fishes and macro-algae on a temperate rocky reef. Journal of Experimental Marine Biology and Ecology, 159(2): 217-235.

JONES, G.P. and ANDREW, N.L. 1990. Herbivory and patch dynamics on rocky reefs in temperate Australasia: the roles of fish and sea urchins. Australian Journal of Ecology, 15(4): 505-520.

KLUMPP, D.W., Mckinnon, D. and DANIEL, P. 1987. Damselfish territories: zones of high productivity on coral reefs. Marine ecology progress series. Oldendorf, 40(1): 41-51.

KOHDA, M. 1984. Intra-and interspecific territoriality of a temperate damselfish Eupomacentrus altus (Teleostei: Pomacentridae). Physiology and Ecology Japan, 21: 35-52.

Litsios, G., PEllissier, L., FOREST, F., LEXER, C., PEARMAN, P.B., ZIMMERMANN, N.E. and SALAMIN, N., 2012. Trophic specialization influences the rate of environmental niche evolution in damselfishes (Pomacentridae). Proceedings of the Royal Society B: Biological Sciences, 279(1743): 3662-3669.

LOBEL, P.S., 1980. Herbivory by damselfishes and their role in coral reef community ecology. Bulletin of Marine Science, 30(1): 273-289.

MONTGOMERY, W.L. 1980. Comparative feeding ecology of two herbivorous damselfishes (Pomacentridae: Teleostei) from the Gulf of California, Mexico. Journal of Experimental Marine Biology and Ecology, 47(1): 9-24.

MYERS, R.F. 1999. Micronesian reef fishes: a comprehensive guide to the coral reef fishes of Micronesia, 3rd revised and expanded edition. Coral Graphics, Barrigada, Guam, 330 pp.

NAIR, R.J. and DINESH KUMAR, S. 2018. Overview of the Fish Diversity of Indian Waters. In: DBT sponsored Three Months National Training in Molecular Biology and Biotechnology for Fisheries Professionals, 2nd February 2015 - 31st March 2018, Kochi.

NELSON, J.S., GRANDE, T.C. and WILSON, M.V. 2016. Fishes of the World. Fifth edition. John Wiley \& Sons, New Jersey, 707 pp. 
PSOMADAKIS, P.N., THEIN, H., RUSSELL, B.C. and TUN, M.T. 2019. Field identification guide to the living marine resources of Myanmar. FAO Species Identification Guide for Fishery Purposes. Rome, FAO and MOALI, 694pp.

RAHMAN, A.K.A., KABIR, S.M.H., AHMAD, M., AHMED, A.T.A., AHMED, Z.U., BEGUM, Z.N.T., HASSAN, M.A. and KHONDOKER, M. (eds.). 2009. Encyclopedia of Flora and Fauna of Bangladesh. Marine Fishes. Asiatic Society of Bangladesh, Dhaka. Vol.24, 485 pp.

RANDALl, J.E., WILliAMS, J.T., D.G. Smith, M. Kulbicki, G.M. Tham, P. Labrosse, M. Kronen, E. Clua and B.S. Mann, 2003. Checklist of the shore and epipelagic fishes of Tonga. Atoll Res. Bull. Nos. 502.

RUSSELL, B.C. 2016. 2016 Survey of coral reef fishes of the Myeik Archipelago, Myanmar. Report No. 38 of the Tanintharyi Conservation Programme, a joint initiative of Fauna \& Flora International (FFI) and the Myanmar Forest and Fisheries Departments. FFI, Yangon, 57 pp.

SAMMARCO, P.W., 1983. Effects of fish grazing and damselfish territoriality on coral reef algae. I. Algal community structure. Marine ecology progress series. Oldendorf, 13(1): 1-14.

THOMPSON, P.M. and Islam, M.A. (Eds.). 2010. Environmental Profile of St. Martin's Island. United Nations Development Programme, Dhaka, 151 pp.

THRESHER, R.E. 1984. Reproduction in reef fishes. TFH. Inc. Ltd., Neptune City, NJ, 399 pp.

TOMASCIK, T., 1997. Management Plan for Resources of Narikel jinjira (St. Martin's Island) Final Report. National Conservation Strategy Implementation Project-1 Ministry of Environment and Forest, Government of Bangladesh, 125 pp.

VENKATARAMAN, K. and RAGHUNATHAN, C. 2015. Coastal and marine biodiversity of India. In: Marine faunal diversity in India.Academic Press, 1st ed., 303-348.

(Manuscript received on 12 February, 2020 revised on 23 June, 2020) 